\title{
RANCANG BANGUN SISTEM MANAJEMEN PROYEK DAN KOLABORASI TIM DEVELOPER
}

\author{
Moch. Fariz Al Hazmi ${ }^{1}$, Ulla Delfana Rosiani,ST.,MT², Nurudin Santoso, ST.,MT ${ }^{3}$ \\ ${ }^{1}$ Jurusan Teknik Elektro, Program Studi Teknik Informatika, Politeknik Negeri Malang \\ Email : ${ }^{1}$ mas.aiz.azmi@gmail.com
}

\begin{abstract}
Abstrak
Mobilitas yang tinggi dan kurangnya kolaborasi antar anggota tim pengembang perangkat lunak mempengaruhi tingginya persentase kegagalan pengerjaan proyek. Komunikasi yang intensif merupakan salah satu faktor yang mempengaruhi keberhasilan pada kolaborasi tim pengembangan perangkat lunak karena tanpa komunikasi yang intensif sering timbul kesalahan pada pengerjaan tugas yang telah ditetapkan oleh manajer proyek dan pengerjaan tidak sesuai rencana. Untuk mengatasi permasalahan-permasalahan tersebut dibuatlah sistem manajemen proyek dan kolaborasi tim developer yang diintegrasikan dengan chat. Sistem tersebut memudahkah manajer proyek untuk mengelola proyek, mengatur penjadwalan proyek, mengatur tim yang terkait pengerjaan proyek, mengatur pembagian tugas pengerjaan proyek, mendokumentasikan aktifitas anggota tim, menganalisa aktifitas yang dicapai tiap anggota tim sepanjang hari selama pengerjaan proyek berlangsung. Sistem dibuat berbasis web, menggunakan teknologi WebSocket, bahasa pemrograman NodeJS dan basisdata MongoDB. Hasil akhir sistem berupa aplikasi web sistem manajemen proyek yang telah diintegrasikan dengan sistem chat. Berdasarkan hasil ujicoba yang telah dilakukan dapat disimpulkan bahwa sistem ini membantu pengelolaan proyek dan memudahkan komunikasi yang intensif dalam berkolaborasi antar tim, sehingga proyek yang dikerjakan maupun tugas yang diberikan kepada anggota tim dapat diselesaikan tepat waktu, hasil produk yang dikerjakan sesuai dengan yang diharapkan dan waktu pengerjaan proyek lebih efisien tanpa mengganggu kolaborasi tim saat pengerjaan proyek.
\end{abstract}

\section{Kata kunci : Chat, Sistem Manajemen Proyek, WebSocket, NodeJS, MongoDB.}

\section{PENDAHULUAN}

Meningkatnya permintaan akan pengadaan aplikasi perangkat lunak menyebabkan mobilitas yang tinggi dalam pengembangan dan pemeliharaan suatu aplikasi perangkat lunak. Hal ini berakibat langsung terhadap pengelolaan proyek perangkat lunak dan pentingnya kolaborasi tim antar anggota tim pengembang perangkat lunak, sehingga perlu diatur dalam sistem manajemen proyek dan kolaborasi tim pengembang perangkat lunak. Manajemen proyek perangkat lunak sangat dibutuhkan karena permasalahan yang sering timbul pada proyek perangkat lunak. Pengelolaan yang kurang baik dapat menyebabkan pembengkakan biaya proyek dan pengerjaan yang tidak sesuai rencana. Waktu dan biaya yang telah dianggarkan oleh pelanggan seharusnya mampu dikelola dengan baik oleh pihak pengembang perangkat lunak. Dengan demikian, target proyek perangkat lunak yang akan dibuat dapat tercapai sesuai tujuan. Sistem manajemen proyek berfungsi untuk membantu mengelola proyek, mengatur penjadwalan proyek, mengatur tim yang terkait pengerjaan proyek, mengatur pembagian tugas pengerjaan proyek, mendokumentasikan aktifitas anggota tim, menganalisa aktifitas yang dicapai tiap anggota tim sepanjang hari selama pengerjaan proyek berlangsung (Rosa dan Shalahuddin, 2011).

Komunikasi yang intensif menjadi faktor penting dalam sebuah sistem manajemen proyek. Hal tersebut merupakan salah satu faktor pendukung pada kolaborasi tim pengembangan perangkat lunak. Tanpa komunikasi yang intensif, maka akan sering muncul kesalahan pada pengerjaan tugas, baik yang telah ditetapkan oleh manajer proyek ataupun yang sudah direncanakan sebelumnya. Kasus demikian sering terjadi pada Software House atau Application Studio sehingga memerlukan solusi agar komunikasi yang intensif tetap dapat dilakukan secara realtime pada saat pengerjaan proyek berlangsung. Salah satu upaya untuk menjaga komunikasi yang intensif adalah dengan memanfaatkan sistem kolaborasi perangkat lunak atau disebut dengan Groupware.Sistem tersebut merupakan suatu teknologi yang dirancang untuk memfasilitasi pekerjaan kelompok. Teknologi ini dapat digunakan untuk berkomunikasi, bekerjasama, berkoordinasi dan 
bernegosiasi dalam menyelesaikan masalah. Beberapa keuntungan menggunakan groupware, antara lain (Reformasi Studi Sarjana, 2009):

a. Untuk memfasilitasi komunikasi, membuat lebih cepat, lebih jelas dan persuasif.

b. Untuk memungkinkan komunikasi dimana saja.

c. Untuk menghemat waktu dan biaya dalam kolaborasi dan koordinasi kerja kelompok.

Di Indonesia, pelaksanaan manajemen proyek dengan memanfaatkan sistem groupware belum pernah dilakukan. Pelaksanaan manajemen proyek hanya sebatas tahap - tahap siklus hidup manajemen proyek tanpa ada kolaborasi anggota tim didalamnya. Oleh karena itu, pada penelitian ini akan dirancang sistem manajemen proyek dan kolaborasi tim dengan integrasi chat. Dengan demikian, sistem tersebut diharapkan dapat membantu pengelolaan proyek pengembangan aplikasi perangkat lunak pada Application Studio atau Software House. Selain itu, sistem ini juga dapat digunkan sebagai alternatif dalam berkomunikasi yang intensif secara realtime selama pengerjaan proyek.

\section{METODE PENELITIAN}

A. Kerangka Penelitian

Penelitian tersebut dilakukan dalam beberapa tahapan seperti pada Gambar 1 .

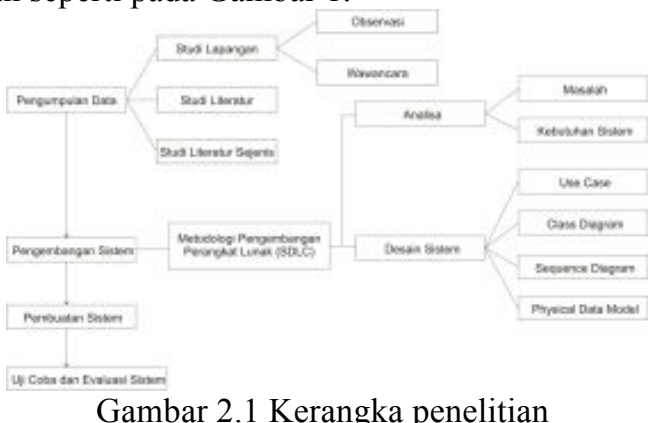

a. Pengumpulan Data

Data kualitatif gambaran proyek diperoleh melalui studi lapangan, studi pustaka dan studi literatur sejenis. Studi lapangan dilakukan dengan cara observasi secara langsung dengan mengamati proses inisiasi proyek, perencanaan proyek, eksekusi proyek dan penyelesaian proyek. Studi literatur dilakukan dengan merujuk pada penelitian yang disusun oleh Nicholas (2012); Nistor dan Nistor (tahun?). Selain itu, pada penelitian ini juga dilakukan wawancara dengan Manajer Proyek divisi Web di Montazze Studio Malang untuk mengetahui menejemen proyek yang sudah dijalankan di tempat tersebut. b. Perencanaan Sistem.

Data yang diperoleh kemudian digunakan untuk membuat permodelan dengan menggunakan Entity Relational Diagram (ERD). Model yang telah jadi kemudian digunakan untuk mengembangkan dan merancang fitur-fitur dalam sistem. Fitur-fitur tersebut meliputi Work Breakdown System (WBS), Use Case, Class Diagram dan Sequence Diagram.

Fitur Work Breakdown System (WBS) menggambarkan semua jenis data yang diproses oleh sistem, layanan dan jenis proses yang dapat dilakukan oleh sistem, serta semua laporan yang ditampilkan kepada pengguna (Gambar 2.2).

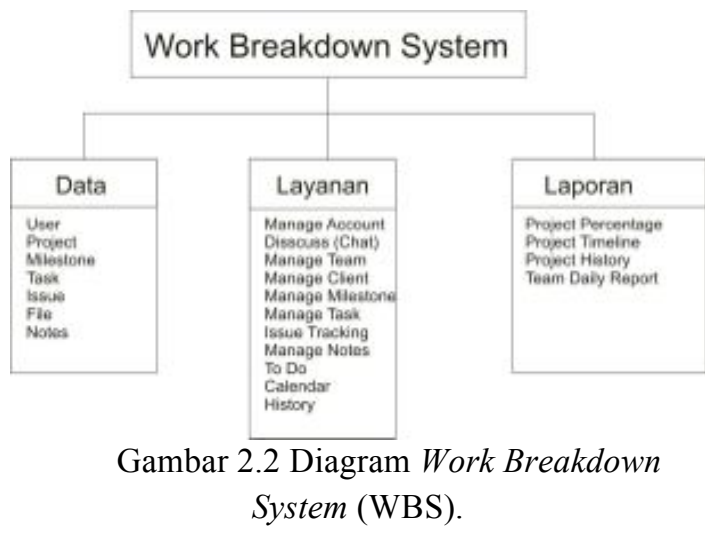

Fitur use case menggambarkan user access level yang memperbolehkan user untuk mengakses dan menggunakan fitur yang dapat dilakukan oleh sistem. Berikut merupakan use case diagram pada sistem manajemen proyek dan kolaborasi tim developer :

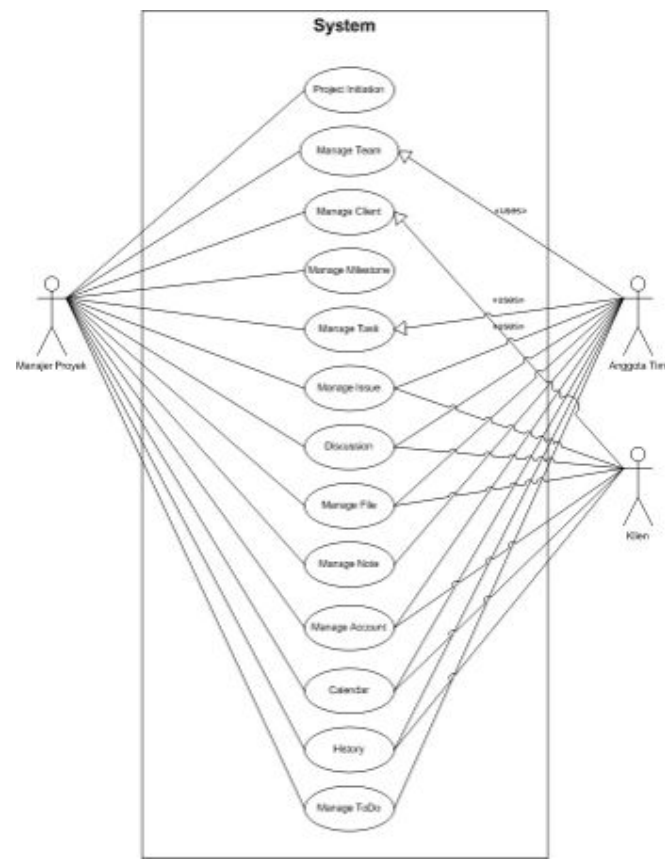

Gambar 2.3 Use Case Initiating Project 
c. Pengembangan Sistem.

Pengembangan sistem dilakukan dengan menggunakan Node JS berbasis bahasa pemrograman Java script, basis data MongoDB dan memanfaatkan fitur HTML 5 WebSocket yang sudah dipustakakan menjadi Socket.io.

d. Uji Coba dan Evaluasi Sistem

Pengujian dilakukan di Montazze Studio Malang terhadap semua fitur sistem yang telah dibuat. Tujuan dilakukan uji coba adalah untuk 1) mengetahui kesesuaian fitur dengan hasil yang diharapkan, 2) mengetahui dan memastikan bahwa sistem manajemen proyek dan kolaborasi tim yang telah dibuat dapat membantu pengelolaan proyek pengembangan aplikasi perangkat lunak dan

\section{HASIL}

Hasil perancangan dan pembuatan sistem yang dilakukan menunjukkan bahwa sistem manajemen proyek dan kolaborasi tim dapat dengan baik diintegrasikan dengan chat. Umumnya, beberapa fitur yang terdapat dalam sistem menejemen proyek di antaranya project initiation, client and team management, milestone management, task management, issue tracking, to do, calendar, history, daily activity, note, file attachment dan discussion yang menerapkan chat.

Fitur-fitur dalam sistem menejemen proyek tersebut merangkum semua hal yang berhubungan dengan proyek yang dikerjakan. Fitur project initiation menangani rencana proyek yang sedang, telah dan akan dikerjakan.

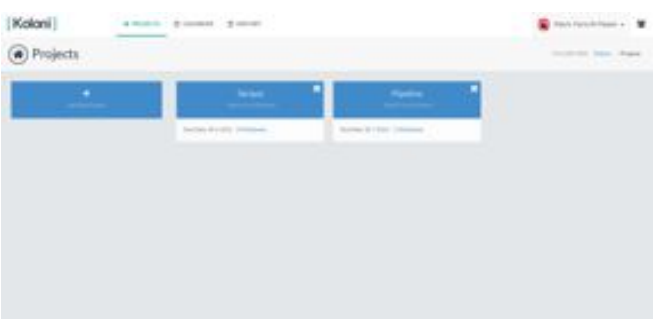

Gambar 3.1 Tampilan Project Initiation.

Fitur client and team management menangani daftar member dan klien yang berkaitan dengan proyek yang sedang dikerjakan.

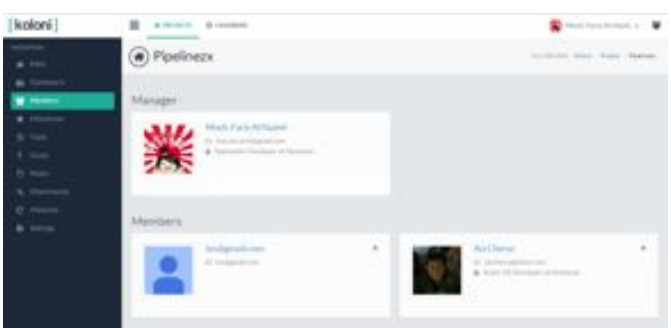

Gambar 3.2 Tampilan client and team management kolaborasi tim di Software House maupun Application Studio, 3) serta untuk mengetahui dan memastikan bahwa integrasi dengan sistem chat dapat menciptakan komunikasi intensif secara realtime atau tidak. Selain itu, melalui uji coba tersebut juga dapat diketahui pengaruh sistem manajemen proyek dan kolaborai tim dengan integrasi chat terhadap produk yang telah dihasilkan dari proses pengembangan aplikasi perangkat lunak.

Jika pada kesalahan pada fitur sistem manajemen proyek dan kolaborasi tim maka dilakukan evaluasi sistem. Jika tidak ditemukan kesalahan pada seluruh fitur, maka sistem secara langsung dapat diaplikasikan.

Fitur milestone management menangani jadwal pelaksanaan milestone dari awal hingga akhir.

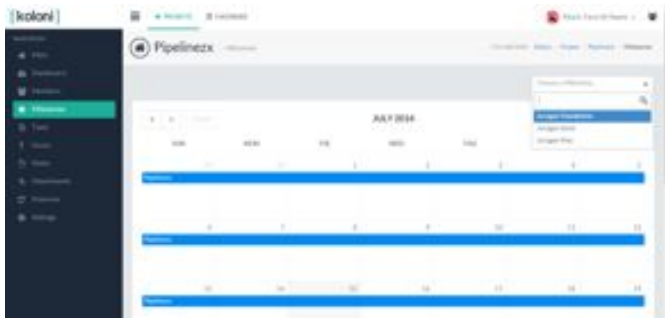

Gambar 3.3 Tampilan milestone management.

Fitur task management menangani daftar tugas yang sedang maupun telah dikerjakan.

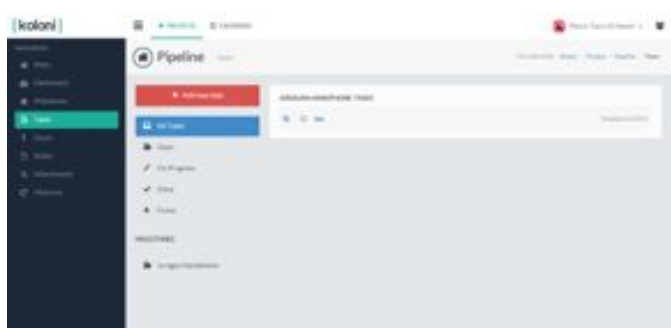

Gambar 3.4 Tampilan task management.

Fitur issue management menangani isu yang merupakan feedback dari klien.

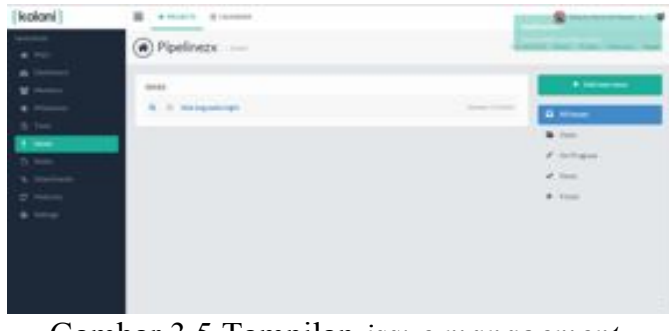

Gambar 3.5 Tampilan issue management 
Fitur to do menangani daftar to do yang telah dibuat oleh pengguna.

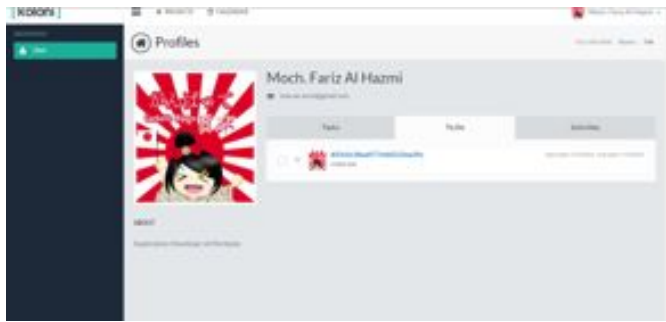

Gambar 3.6 Tampilan todo.

Fitur calendar menampilkan keseluruhan jadwal pelaksanaan proyek.

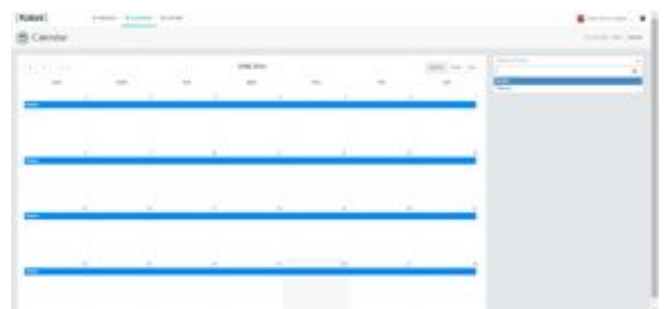

Gambar 3.7 Tampilan calendar.

Fitur history menampilkan semua aktifitas dalam sebuah proyek.

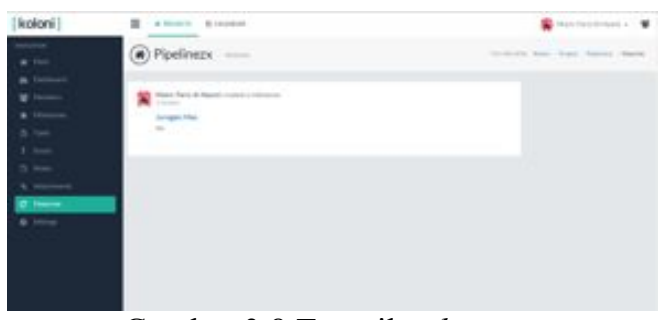

Gambar 3.8 Tampilan history.

Fitur daily activity menampilkan semua aktivitas yang dilakukan seorang user selama menggunakan sistem.

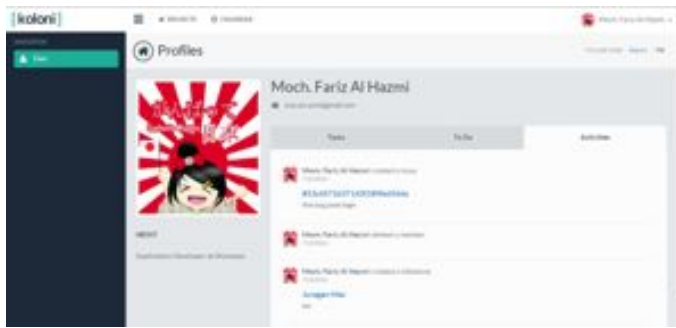

Gambar 3.9 Tampilan daily activity.

Fitur note management menangani pengelolaan note yang telah dibuat manajer proyek maupun anggota tim.

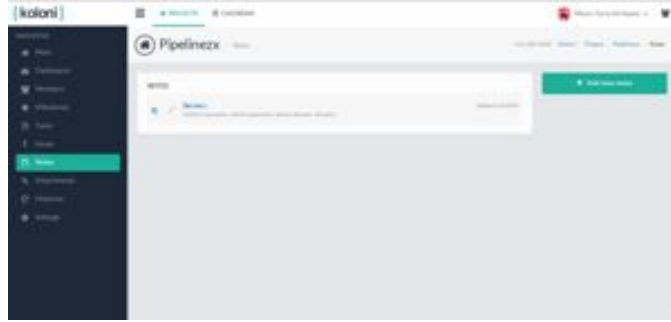

Gambar 3.10 Tampilan note management.

Fitur file attachment menangani semua file yang dilampirkan untuk mendukung menejemen proyek.

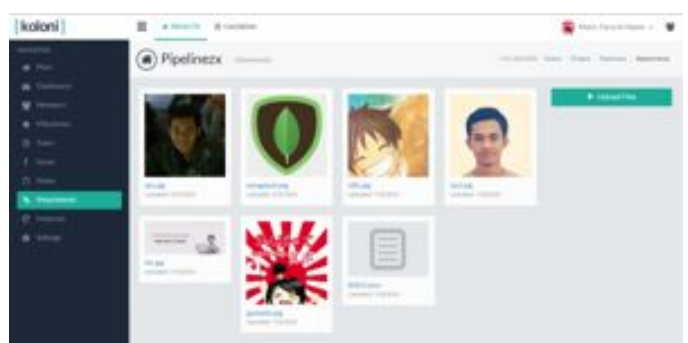

Gambar 3.11 Tampilan file management.

Fitur discussion yang memudahkan penggunakan dalam mendiskusikan hal-hal yang berkaitan dengan proyek yang dilakukan

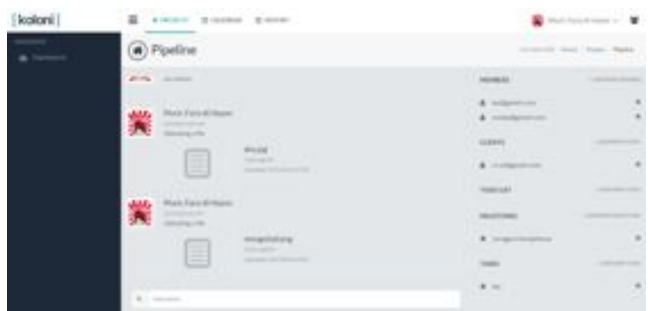

Gambar 3.12 Tampilan discussion.

\subsection{Pengujian Sistem}

Sistem yang dihasilkan diuji coba di Montazze Studio dengan pengujian fungsionalitas sistem.. Pengujian sistem dilakukan untuk mengetahui apakah setiap fitur pada sistem yang telah dihasilkan sudah sesuai dengan yang diharapkan. Sistem diuji coba dengan skenario dengan proyek bernama Loakin. Loakin merupakan classified web apps yang berfungsi sebagai website untuk menjual barang - barang bekas yang masih dapat digunakan. Fitur yang harus ada pada Loakin yaitu autentikasi menggunakan sosial media Facebook, mengelola barang, upload foto, mengelola akun pengguna, dan pencarian produk. Proyek dimulai pada tanggal 16 Juli 2014 - 22 Juli 2014. Proyek dipimpin oleh 1 orang manajer proyek, dikerjakan oleh 2 orang anggota tim dan diawasi 2 orang klien. Dalam sebuah proyek dibuat 2 milestone, desain user interface dan pengembangan sistem. Milestone desain user interface dimulai tanggal 16 Juli 2014 - 18 Juli 2014, sedangkan milestone pengembangan sistem 
dimulai tanggal 16 Juli - 21 Juli 2014. Tugas pada milestone desain user interface antara lain desain PSD, dan HTML. Sedangkan tugas pada milestone pengembangan sistem antara lain membuat autentikasi yang diintegrasikan menggunakan Facebook, upload foto, manajemen produk, manajemen akun pengguna dan pencarian produk.

Dari hasil ujicoba, sistem yang telah dibuat telah berjalan dengan baik secara fungsional dan menghasilkan output yang diharapkan.

\section{PEMBAHASAN}

Setelah sistem diujicoba berdasarkan skenario yang telah dibuat. Survey dilakukan pada CTO Montazze Studio yang berperan manajer proyek pada skenario yang telah dibuat untuk mengetahui apakah pelaksanaan proyek pada Montazze Studio sudah sesuai dengan siklus hidup proyek dan apa saja yang menjadi kendala pada saat pelaksanaan proyek sebelum sistem diimplementasikan. Survey yang telah dilakukan sebagai berikut.

\begin{tabular}{|l|l|}
\hline \multicolumn{2}{|c|}{ Form Survey } \\
\hline Nama & Septiyan Andika \\
\hline Divisi & $\begin{array}{l}\text { CTO / Mobile Division } \\
\text { Manager }\end{array}$ \\
\hline $\begin{array}{l}\text { Jumlah Anggota } \\
\text { Tim }\end{array}$ & 4 \\
\hline $\begin{array}{l}\text { Rata - rata jumlah proyek yang dikerjakan dalam 1 } \\
\text { bulan / divisi? }\end{array}$ \\
\hline 3 Proyek. \\
\hline $\begin{array}{l}\text { Permasalahan apa yang sering anda hadapi pada } \\
\text { saat pengerjaan proyek? }\end{array}$ \\
\hline $\begin{array}{l}\text { Delegasi task kepada masing-masing anggota } \\
\text { team dan komunikasi. }\end{array}$ \\
\hline $\begin{array}{l}\text { Apakah anda pernah mendengar atau mengetahui } \\
\text { tentang Sistem Manajemen Proyek? }\end{array}$ \\
\hline $\begin{array}{l}\text { Pernah } \\
\text { Sistem Manajemen Proyek? }\end{array}$ \\
\hline Ya, sudah \\
\hline Yetelah menggunakan sistem manajemen proyek \\
\hline
\end{tabular}

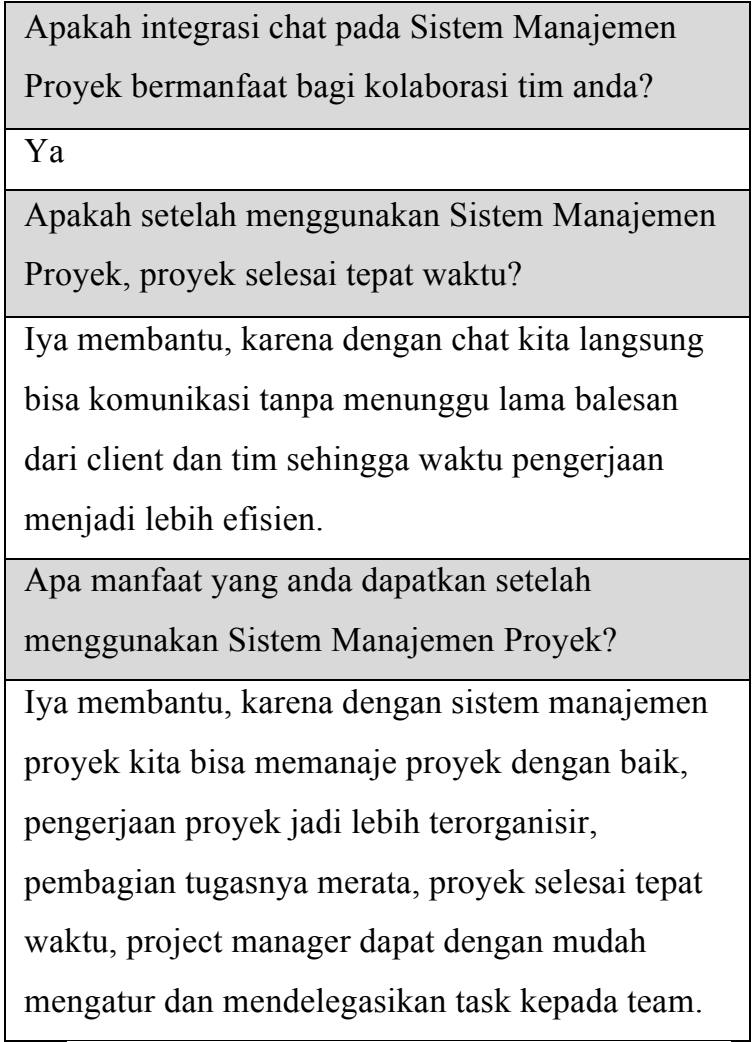

Dari hasil survey yang telah dilakukan, terdapat kendala pada tahap perencanaan proyek dalam mendelegasikan tugas kepada anggota tim dan komunikasi pada saat kolaborasi pengerjaan proyek antar anggota tim. Kendala - kendala tersebut dapat ditangani oleh sistem yang telah dibuat. Pendelegasian tugas dapat dilakukan pada fitur task management, sehingga project manager dapat mendelegasikan tugas kepada anggota timnya dan permasalahan komunikasi dalam berkolaborasi dengan anggota tim dapan ditangai melalui realtime chat yang telah diintegrasikan. Selain itu juga dapat diambil kesimpulan bahwa dengan menggunakan sistem manajemen proyek, membantu manajer proyek memanaje proyek dengan baik, pembagian tugasnya merata, proyek selesai tepat waktu dan produk yang dihasilkan sesuai dengan yang diinginkan. Sedangkan dengan mengintegrasikan sistem chat pada sistem manajemen proyek, memudahkan komunikasi yang intensif dalam berkolaborasi antar tim. Komunikasi dengan klien maupun anggota antar tim lebih cepat dan waktu untuk berkomunikasi secara langsung (bertatap muka) juga berkurang sehingga waktu pengerjaan proyek lebih efisien tanpa mengganggu kolaborasi tim saat pengerjaan proyek.

\section{KESIMPULAN DAN SARAN}

\subsection{Simpulan}

Berdasarkan pembahasan pada bagian sebelumnya ditarik kesimpulan bahwa :

1. Sistem manajemen proyek dan kolaborasi tim developer yang telah 
dibuat berjalan dengan baik secara fungsional dan menghasilkan output yang diharapkan sehingga membantu pengguna dalam mengelola proyek.

2. Integrasi chat pada sistem manajemen proyek memudahkan komunikasi yang intensif dalam berkolaborasi antar tim. Komunikasi antar tim lebih cepat dan waktu untuk berkomunikasi secara langsung (bertatap muka) juga berkurang sehingga waktu pengerjaan proyek lebih efisien tanpa mengganggu kolaborasi tim saat pengerjaan proyek.

3. Manfaat penggunaan sistem manajemen proyek adalah bermanfaat dalam membantu pengelolaan proyek dengan kesibukan yang tinggi sehingga proyek yang dikerjakan maupun tugas yang diberikan dapat diselesaikan tepat waktu dan hasil produk yang dikerjakan sesuai dengan yang diharapkan.

\subsection{Saran}

Pengembangan sistem manajemen proyek selanjutnya, sebaiknya dikembangkan dengan fitur integrasi dengan repository, push nofitication, realtime chat diintegrasi dengan instant messaging pada aplikasi mobile agar kolaborasi pengerjaan proyek anggota tim dapat terkontrol dengan baik.

\section{DAFTAR RUJUKAN}

Arson, Meirza. 2011. HTML5 WebSocket. http://virtuemagz.com/html5-websocket.html. (Diakses pada tanggal 2 Februari 2014).

Azrahinelo, 2013. Makalah manajemen proyek sistem informasi http://www.slideshare.net/azrahinelo/maka lah-manajemen-proyek-sistem-informasi. (Diakses pada tanggal 11 Mei 2014).

C. Nicholas."Collaborative Project Management Software". Proceedings of the 35th Hawaii International Conference on System Sciences. 2012.

Iwan, Kurniarasa. 2013. Metode Pengujian Blackbox.

http://www.slideshare.net/iwankurniarasa/ metodepengujianblackbox. (Diakses pada tanggal 21 Juli 2014).

Kaazing. 2013. About HTML5 WebSockets . http://www.websocket.org/aboutwebsocke t.html. (Diakses pada tanggal 2 Februari 2014).

Kersen. 2013. Development dengan Node.JS. http://www.kersen.co.id/2013/04/develop ment-dengan-node-js. (Diakses pada tanggal 16 Januari 2014).

MongoDB. 2009. MongoDB Manual. http://docs.mongodb.org/manual. (Diakses pada tanggal 16 Januari 2014).

Mustofa. 2013. MongoDB Part 1: Pengenalan Document-Oriented MongoDB. http://bisakomputer.com/mengenalmongodb-part-1. (Diakses pada tanggal 16 Januari 2014)

NISTOR, Rozalia, NISTOR, Costel. "Groupware Modern Information Managerial Method". Dunarea de Jos University of Galati. 2012.

Node.JS. 2009. About Node.JS http://www.nodejs.org/about. (Diakses pada tanggal 16 Januari 2014).

Nugrahanto Bagus. 2013. Makalah HTML5. Universitas Negeri Semarang.

Prayatni, Soewondo, Sembiring, Emenda (2013). Siklus Hidup Manajemen Proyek. ridwanreza.files.com (Diakses pada tanggal 11 Mei 2014).

Purnomosidi, Bambang. 2013. Pengembangan Aplikasi Cloud Computing Menggunakan Node.js.

http://www.slideshare.net/bpdp/pengemba ngan-aplikasi-cloud-computingmenggunakan-nodejs. (Diakses 2 Februari 2014).

Reformasi Studi Sarjana, 2009. Groupware Introduction.

http://pps.teithe.gr/Groupware.pdf (Diakses pada tanggal 11 Mei 2014).

Rosa A.S, M. Shalahuddin. 2011. Modul Pembelajaran Rekayasa Perangkat Lunak (Terstruktur dan Berorientasi Objek). Penerbit Modula.

Stikom Edu. 2012. Proyek dan Manajemen Proyek. http://ocw.stikom.edu/course/download/20 12/10/Manajemen-PSI-02-Proyek-danManajemen-Proyek. (Diakses pada tanggal 3 Februaru 2014).

Wibowo, Ary. 2012. Metode Pengembangan Perangkat Lunak. http://blog.arywibowo.com/2012/05/metod e-pengembangan-perangkat-lunak.html. (Diakses pada tanggal 2 Februari 2014). 